\title{
Overview Success Criteria and Critical Success Factors in Project Management
}

\author{
Frefer AA ${ }^{1}$, Mahmoud $\mathbf{M}^{1}$, Haleema $\mathrm{H}^{2}$ and Rabia Almamlook ${ }^{3 *}$
}

${ }^{1}$ Mechanical and Industrial Engineering Department, University of Tripoli, Tripoli, Libya

${ }^{2}$ Engineering Management Department, University of Tripoli, Tripoli, Libya

${ }^{3}$ Department of Industrial Engineering and Engineer Management, Western Michigan University, Kalamazoo, MI, USA

\begin{abstract}
This paper covers a thorough overview of project success, project success criteria and critical success factors for projects. There is no consensus among researchers of what constitutes projects success. Also considering that a project is successful or a failure, depending exclusively on whether it meets or fails the criteria for time, cost and quality is outdated and it's the narrow view, also in fact criteria for project management success. The surest way to perceive project success is examining its alignment with strategic organizational objectives. In order to achieve both project management success and project success it is important to identifying project success criteria and critical success factors at the initial stage of a project. Sustainability is becoming a critical topic and attracting researchers in recent years. The traditional criteria clearly put the emphasis on economic aspects and the social and environmental pillars get less attention because companies survival in the long-term depends on their ability to be profitable. The harmony between economic, social and environmental are required in project management. The purpose of this chapter is mainly to investigate the criteria for measuring the success of a project and the key factors of project successes, which practitioners can make use of to eliminate failures and thus improve project success.
\end{abstract}

Keywords: Project success; Project management success; Success criteria; Critical success factors; Sustainability in project management

\section{Introduction}

The organizations are recognizing that translating corporate strategies into actions requires projects. Consequently, it is vital that projects are successful. According to several authors, including Shenrar et al. [1], Baccarini [2], De Wit [3], Wateridge [4], Munns and Bjeirmi [5], Liu and Walker [6], Cooke-Davies [7], Khosravi et. al. [8], one theme within project management that is frequently discussed but seldom agreed upon concerns the notion of project success. Which was emphasized by Els et al. [9], conclude that most researchers have agreed to disagree on what constitutes project success. Prabhakar [10], stated that neither the practitioners nor the academicians seem to agree on what constitutes project success, and it seems to be a rather elusive concept.

According to Kerzner [11], the definition of project success has changed over the years. Project success means different to different stakeholders [12], this led to disagreements, because of varying perceptions and perspectives, as to whether a project is successful or not. Collins and Baccarini [13], arrived at the conclusion that there is a positive relationship between project management success and project success. Munns and Bjeirmi [5] argue that successful project management will contribute to the achievement of projects, but it will not stop a project from failing to be successful. Turner [14] suggests there is no point in determining success factors until one has identified the success criteria in the first place. Which was emphasized by Yusof et al. [15] noted that the success factors alone, project success would not be perfect without the success criteria. In recent years, researchers in project management have become increasingly interested in project success criteria and critical success factors. In order to achieve both project management success and project success. Projects are the main part of a business, and therefore, it is evident that when the strategy of a company is to act sustainable, this must result in actions in their projects, $[16,17]$ many researchers have been confirmed that sustainability has become one of the most important challenges of today's society. The relationship between project management and sustainability is explored as one of the future developments in project management since companies feel the external pressure to include principles of sustainable development in their business. This clarify is why organizations keen on to include sustainability in their business.

\section{Project Success and Project Management Success}

Early studies in the mid-1900s linked to project management and project success to the triple objectives of Time, Cost and Quality [18]. It is important to differentiate between project success and project management success. De Wit [3] seems to be among the first to note that project success is measured against the overall objectives of the project and project management success is measured against the traditional measures of performance against cost, time and quality. Baccarini [2] also pointed out that project success divided to product success that deals with goal and purpose, and project management success that deals with outputs and inputs.

According to Munns and Bjeirmi [5] stated that the difference between the success of a project and the success of the project management that due to the difference between project management which be short-term objectives, and project success which is longterm objectives. Silva et al. [19] noted that there is no such thing as an absolute success in a project and there is only perceived success.

*Corresponding author: Rabia Almamlook, Department of Industrial Engineering and Engineer Management Western Michigan University, Kalamazoo, MI, USA Tel: 2692763253; E-mail: rabiaemhamedm.almamlook@wmich.edu

Received December 12, 2017; Accepted December 29, 2017; Published January 05, 2018

Citation: Frefer AA, Mahmoud M, Haleema H, Almamlook R (2018) Overview Success Criteria and Critical Success Factors in Project Management. Ind Eng Manage 7: 244. doi:10.4172/2169-0316.1000244

Copyright: ( 2018 Frefer AA, et al. This is an open-access article distributed under the terms of the Creative Commons Attribution License, which permits unrestricted use, distribution, and reproduction in any medium, provided the original author and source are credited. 
Al-Ageeli and Alzobaee [20] stated that the measuring of the project success is a complex task since the success is intangible and hardly be agreed upon. Abdullah et al. [18] see project success as a quite elusive.

Project success is suggested to have two major components: issues dealing with the project itself and issues dealing with the client [21]. Lim and Muhammad [12] classify project success into two categories: the macro and micro project success. The macro viewpoint of project success considers the original project concept and if that is achieved, the project is successful. On the other hand, micro viewpoint of a project, success considers project achievement in smaller component levels. Ghasabeh and Chabok [22] in their survey's results show that $43 \%$ of the professionals surveyed believed that project success is indeed projected management success while $46 \%$ of respondents indicated that they are totally different. Also, Omer and Haleema [23] their results show that $48 \%$ of the professionals surveyed believed that project success is indeed projected management success while $52 \%$ of respondents indicated that they are totally different. We can say that the concept of project success has still ambiguous in the minds of professionals.

According to Iram et al. [24] in the past years the simple definition for the success of the project was only based on the implementation phase of the project lifecycle. But in these days the definition of the project success is required from the beginning till the end of the project and product life cycles. Prabhakar [10] argued that good schedule and cost performance means very little in the face of a poor performing end product. Munns and Bjeirmi [5] stated that project management and its techniques are only a subset of the wider context of the project. Projects can succeed or fail independently of the project management process. Judging a project's success within an organization must take into account that the project contributing in an archive to the organization's strategic objectives, it cannot be limited to the efficiency of the project management processes employed $[24,25]$.

This statement has been confirmed by some other researchers. For example, Osorio et al. [26] stated that the projects are ways to implement strategies, and a project's objectives must be directly connected to the organization's strategic objectives. And it is having been strongly emphasized by Wan Abdullah et al. [18] most projects are part of their organizations' strategic management and must be evaluated based on their contributions to the business' results. Pinto and Selvin, [21] see a project success as a complex and often illusory construct, but nonetheless, it is of crucial importance to effective project implementation. From the review of the literature on project success, it is clear that project success is something much more complex than simply meeting cost, schedule, and performance specifications. Today we know that determining whether a project is a success or failure is far more complex.

\section{Success Criteria in Project and Project Management}

There are several success criteria that have been studied in order to state the issue of project success the previous decades. A criterion can be defined as "the principle or standard by which something can be judged or decided" [20]. Project success criteria are the dependent variable which measures success [27]. Success criteria as the benchmark to measure or judge success $[7,12]$. Traditionally project success criteria focused on cost, time and quality, these criteria are no longer sufficient to measure the success of the project [28]. Many researchers suggest that success can't be accessed only through this three criteria since project success is more complex [29]. Nicholas [30] stated that the best overall criterion for project success is when the user, project manager and system development group all think their expectations were met or exceeded.

Along the same line, current project management guides, such as PMBOK (PMI, 2013), still place an emphasis on the delivery of projects within the constraint of time, cost and scope also referred to as the iron triangle [31]. More specifically, project objectives will tend to be either qualitative and not easily measured in any objective manner, or longer-term and not are easy to criteria quantitatively measurable immediately, on the contrary project management objectives that are cost, time and quality that is the point at which project management ends. This makes it convenient to use criteria of project management success as a means of determining overall project success [5]. This leads to a reference the project management criteria being a subset of all project criteria.

According to Abdullah et al. [18] stated that in the 60's and 70's the outlook regarding the project success criteria began to expand beyond the time, cost and quality. Then in the 1980s until late 1990s, further studies have begun to research deeper in defining project success criteria, where it was concluded that apart from the iron triangle of time, cost, and quality, their other criteria affect the success or failure of a project. As in the project success literature, the project success criteria hardly agreed upon in literature. Westerveld [32] pointed out success criteria will differ from project to project.

However, Prabhakar [10] stated that criteria for measuring project success must, therefore, reflect different views. Baccarini [2] asserts that the criteria for measuring project success must be set out at the beginning of the project to enable the project team members to work in the same direction. Pinto and Selvin, [21] identified six project success criteria for measuring the success of projects. Freeman and Beale [33] reviewed the project management literature, identified seven main criteria for measuring the success of projects. Khosravi and Afshari [34] identified five project success criteria for measuring the success of construction projects. Bryde and Robinson [35] identified five criteria for project success. Also, Bahia, [36] identified eight success criteria in offshore engineering, procurement and construction projects in Brazil. According to Al-Tmeemy et al. [37] in their results showed that nine criteria that provide an appropriate judgment of success at all stages of the project, three of which are criteria that referred to the success of the project management that is short-term goals and three criteria which referred to as the project success that is the medium-term goals.

As well as three criteria referred to as the success of the end result in the long term of the project's lifecycle. Gomesa and Romaoa [38] identified five project success criteria for project success. Mukhtar and Amirudin, [39] their results reveal six criteria for measuring public housing project management success and four criteria for measuring public housing product success. Omer and Haleema [23] identified fifteen project success criteria for oil and gas project success in Libya. Their findings indicate that the traditional measures of the iron triangle time, cost, and quality are no more applicable to measuring performance on oil and gas projects, however, they did not distinguish between key performance indicators and success criteria, describing both as metrics used to measure the performance and success. ALTmeemy et al. [37] in their study results indicated that a categorization scheme for success criteria for building projects should include the categories of project management success, product success, along with market success. Toor and Ogunlana [40] stated that success of future projects will be increasingly measured by the criteria of strategy, sustainability, and safety. 
The second important distinction in this paper is the difference between success criteria and success factors, the success criteria are measures in comparison with it the project success or failure can be a judge; while the success factors can be defined as " those entered to the management systems result indirectly or indirectly" [2]. From the literature review we can easily see that there is a lack of agreement concerning the criteria by which success is judged. The projects end when they are delivered to the customer. That is the point at which project management ends. They do not consider the wider criteria which will affect the project once in use. Summary of the literature on project success criteria and success factors is shown in Table 1.

\section{Critical Success Factors in Project Management}

The concept of "success factors" was coined in 1961 by D. Ronald Daniel of McKinsey \& Company, it was refined into critical success factors in1981 by John F Rockart, since then many authors have published lists of critical success factors (CSFs). Rockart, [41] defined critical success factors as "the limited number of areas in which satisfactory results will ensure successful competitive performance for the individual, department or organization". Baccarini and Collins, [42] see a project's critical success factors as "important influences that contribute to project success" [27].

Amade1 et al. [43] stated that critical success factors are the few key variables or factors that the manager should prioritize in other to achieve his/her goals for current or future areas of activity. According to Alias et al. [44] critical success factors are inputs to project management practice which can lead directly or indirectly to project success. Effective and efficient management of critical success factors is the basic requirement of project success [24]. According to Baccarini [45] stated that to increase the chances of a project succeeding it is necessary for the organization to have an understanding of what are the critical success factors, to systematically and quantitatively assess these critical factors, anticipating possible effects, and then choose appropriate methods of dealing with them.

There are many researchers who conducted different researchers in order to find out various critical success factors for the project success. Pinto [46] identified ten critical success factors related to successful implementation. Kerzner [47] identified six critical success factors for successful projects. Pinto and Prescott [48] studied ten critical success factors at each of the four stages of the project lifecycle. Belassi and Tukel [49] they presented critical success factors, they grouped these factors into four areas: factors related to the project, project manager and the team members, the organization and the external environment. Cooke-Davies [7] he stated that the development of CSF is related to answers the following questions: "what factors lead to project management success?", "what factors lead to a successful project?" and "what factors lead to consistently successful projects?".

Baccarini and Collins [42] identified fifteen critical success factors for projects. Fortune and White [50] reviewed sixty-three publications on critical success factors (CSFs). As a result of their work provided twenty-seven critical factors. Anderson et al. [51] studied the relationship between project success factors and actual project success. And nine critical success factors identified. Khan and Spang [52] classified critical success factors into four dimensions: organization factors, project factors, people factors and national factors in a way to highlight the extent of influence of national factors on international projects. They found out that the success of any international project is largely influenced by the national factors. Fiberesima and Rani [53] identified thirteen critical success factors are of high importance within the deep-water oil and gas project portfolio management. Pakseresht and Asgari [54] identified twenty-six critical success factors in construction projects.

More recently, there is an increasing number of researchers on critical success factors, for example, Gudienè et al. [55] identified ten critical success factors that are of great significance both to researchers and industry practitioners for construction projects in Lithuania. Almajed and Mayhew [56] identified eight critical success factors of IT projects in Saudi Arabian public organizations. Ofor, [57] identified four CSFs that lead to the success of projects in Ghana. Adnan et al. [58] identified six factors that considered as critical for construction project success and found out that there is a set of different critical success factors for the different objectives which are time, cost and quality.

Amade et al. [43] identified six critical success factors of the public-sector construction project in Owerri, Imo State of Nigeria. AlAgeeli and Alzobaee [20] identified twelve critical success factors and thirteen critical failure factors in construction projects. As one of the first studies in its kind Banihashemi et al. [59] proposed a set of CSFs for integration of sustainability into project management practices on construction projects. Wang et al. [60] identified eleven critical factors for sustainable project management. Omer and Haleema [23] in their research classified critical success factors into five groups: factors related to the company, factors related to the project management, factors related to the project manager and project team, factors related to the contractor and factors related to the environment. \{How many CSF (Total)? We think more than 80 , for sure there are many similar CSFs, but if we will state all it, it will be extra information and too long paper\}.

\begin{tabular}{|c|c|c|}
\hline No. & Success Criteria (CS) & Source \\
\hline 1 & Cost, Time, Performance, Satisfaction, Use, Effectiveness & [21] \\
\hline 2 & $\begin{array}{l}\text { Technical performance, Efficiency of project execution, Managerial and organizational implications, Personal growth, Project termination, } \\
\text { Technical innovativeness, Manufacturability and business performance. }\end{array}$ & [33] \\
\hline 3 & Time Performance, Cost Performance, Quality Performance, Health, Safety and Environment (HSE), Client Satisfaction. & [34] \\
\hline 4 & Cost, Time, Meeting the technical specification, Customers' satisfaction, Stakeholders, satisfaction. & [35] \\
\hline 5 & Cost, Time, Quality, Scope, Customer Satisfaction, Safety, Team Satisfaction, Shareholder Satisfaction. & [36] \\
\hline 6 & $\begin{array}{l}\text { Cost, Quality, Time, Customer Satisfaction, Technical Specifications, and Functional Requirements, Revenue and Profits, Competitive } \\
\text { Advantage, Market Share, Reputation. }\end{array}$ & [37] \\
\hline 7 & Cost, Time, Technical Requirements, Customer Satisfaction, Objectives Achievement. & [38] \\
\hline 8 & $\begin{array}{l}\text { Client's satisfaction, Project completed on time, Project completed to specified quality standard, Absence of disputes, safety, Completion } \\
\text { within budget. }\end{array}$ & [39] \\
\hline 9 & $\begin{array}{l}\text { Quality, Time, Cost, Health, Safety and Environment (HSE), Scope, Customer' Satisfaction, Efficiency of use resource, Effectiveness } \\
\text { Productivity, Profitability, Shareholder satisfaction, Experience gain from the project, Achievement of project's objectives, Sustainability, } \\
\text { Reliability }\end{array}$ & [23] \\
\hline
\end{tabular}

Table 1: Summary of success criteria (CS) from literature reviewed in this paper. 
According to Westerveld [61] in both theory and practice, need to relate critical success factors to project success criteria. Iram et al., [24] their findings of this study show that both critical success factors and project success have very close and significant relationship with each other. Wateridge [61] suggests selecting the CSFs at the outset of a project and clarify the success criteria accordingly so that all stakeholders appear to agree on it. Alias et al. [44] stated that study of project success and critical success factors is considered as one of the vital ways to improve the effectiveness of project delivery. Review of literature on CSFs shows that the issue of critical success factors in projects has been researched extensively in the past and present. Generally, critical success factors are a set of project variables or factors that are strongly related to project success and lead to project success, when managing these factors in the best possible manner.

\section{Sustainability in Project Management}

The relationship between project management and sustainable development is rapidly gaining interest from both practitioners and academics recently. Silvius et al. [62] have been confirmed that the relationship between sustainability and project management is still an emerging field of a stud. Silvius and Schipper, [63] they stated that the logic behind this relationship is that sustainability needs change and projects are realizing change. Silvius et al. [62] in their study concluded that in the near future the attention to sustainability in projects will grow. Along with academics, practitioners have also expressed an interest in understanding the linkage between sustainable development and project management. The Brundtland Report gives the most adopted definition of sustainable development, which is "to meet the needs of the present without compromising the ability of future generations to meet their own needs" [64]. Elkington, [65] stated that sustainability is about the balance or harmony between economic sustainability, social sustainability, and environmental sustainability. Silvius and Schipper [63] stated that the balance between economic growth and social wellbeing has been around as a political and managerial challenge for over 150 years.

Despite the rising attention on clarifying the fundamentals of sustainable project management, only a few authors have attempted to define the concept. Tam [66] incorporates all three pillars of sustainability, social, environmental and economic, in his definition by urging for a promotion of positive and reduction of negative sustainability impacts over project phases. Ning et al. [67] emphasized the need to undertake business activities without negatively impacting future generations through a diminishing use of finite resources, energy, pollution, and waste. Based on concepts, Silvius et al. [62], a definition of sustainable project management, is "the management of project-organized change in policies, assets or organizations, with consideration of the economic, social and environmental impact of the project, its result and its effect, for now and future generations".

Sustainability in project management is about integrating economic, environmental and social aspects in the content and management of projects. In current project management methodologies, the management of projects is dominated by criteria of time, cost, and quality. The traditional criteria clearly put the emphasis on economic aspects and the social and environmental pillars get less attention. Sadaba et al. [68] suggested that sustainability seems at first to be counter to traditional project management in which almost all aspects are superimposed on the investment's economic profitability. And assert that sustainability and environmental issues are not specifically or systematically considered in most major project management frameworks such as PMBOK, ICB, ISO 21500:2012 and Prince2. And noted that transforming strategic sustainability objectives into specific actions for projects is a complicated process. Also, conditions for sustainable development are difficult to achieve and even more difficult to demonstrate.

\section{Conclusion}

From literature review show, there is a lack of agreement concerning the criteria by which success is judged. A project can be completed on time within budget but considered as a failed project if it did not meet company strategic objectives. Thus, project success and project management success are not the same. Failure could be avoided by paying careful attention to the project management success criteria and critical success factors which if it absent cause failure. Project success is often assessed only at the end of the project lifecycle, as project management outcomes are available and convenient to measure. The right project will succeed almost without the success of project management, but successful project management could enhance its success. Despite the fact that the success of projects has started to be assessed using multiple criteria, but still, the social and environmental pillars get less attention. Trying to establish a set of accepted project success criteria seems like an endless effort.

\section{References}

1. Shenhar AJ, Levy O, Dvir D (1997) Mapping the Dimensions of Project Success. Project Management Journal 28: 5-9.

2. Baccarini D (1999) The Logical Framework Method for Defining Project Success. Project Management Journal 30: 25-32.

3. De Wit A (1988) Measurement of Project Success. International Journal of Project Management 6: 164-170.

4. Wateridge JH (1995) IT Projects; A Basis for Success. International Journal of Project Management 13: 169-172.

5. Munns AK, Bjeirmi BF (1996) The Role of Project Management in Achieving Project Success. International Journal of Project Management 14: 81-87.

6. Liu AM, Walker A (1998) Evaluation of Project Outcomes. Construction Management and Economics 16: 209-219.

7. Cooke Davies TJ (2002) The Real Success Factors in Projects. Internationa Journal of Project Management 20: 185-190.

8. Khosravi S, Afshari H (2011) A Success Measurement Model for Construction Projects. International Conference on Financial Management and Economics 11: $186-190$

9. Els M, Van der Merwe MF, Hauptfleisch AC (2012) Critical success criteria and success Factors in Project Management: A Quest to Enhance Generic Professional Practice. 11th International Conference on Entertainment Computing Bremen, Germany: ICEC.

10. Prabhakar G (2008) What is Project Success: A Literature Review. International Journal of Business and Management 26: 3-10.

11. Kerzner H (1998) In Search of Excellence in Project Management. Van Nostrand Reinhold New York.

12. Lim CS, Mohamed MZ (1999) Criteria of Project Success: An Exploratory ReExamination. International Journal of Project Management 17: 243-248.

13. Collins, A, Baccarini D (2004) Project Success-A Survey. Journal of Construction Research 5: 211-231.

14. Turner JR (1999) Project Management: A Profession Based on Knowledge or Faith. International Journal of Project Management 17: 329-330.

15. Yusof AM, Ismail S, Han WS, Aun CN (2012) Reviewing the Notions of Construction Project Success. International Journal of Business and Management 7: 90-101.

16. Oehlmann I (2011) The Sustainable Footprint Methodology, Lambert Academic Publishing, Cologne. 
Citation: Frefer AA, Mahmoud M, Haleema H, Almamlook R (2018) Overview Success Criteria and Critical Success Factors in Project Management. Ind Eng Manage 7: 244. doi:10.4172/2169-0316.1000244

Page 5 of 6

17. Silvius AG, Schipper R (2014) Sustainability in Project Management Competencies: Analyzing the Competence Gap of Project Managers. Journal of Human Resource and Sustainability Studies 2: 40-58.

18. Wan Abdullah, Wan Maimun, Ramly A (2006) Does Successful Project Management Equates to Project Success. International Conference of Cognitive Informatics Beijing, China.

19. Silva GK, Warnakulasuriya BF, Arachchige BH (2016) Criteria for Construction Project Success: A Literature Review, International Conference on Business Management.

20. Al-Ageeli HK, Alzobaee AA (2016) Critical Success Factors in Construction Projects (Governmental Projects as a Case Study). Journal of Engineering 22 129- 147.

21. Pinto JK, Slevin DP (1988) Project Success: Definitions and Measurement Techniques. Project Management Journal 19: 67-72.

22. Ghasabeh MS, Chabok KK (2009) Generic Project Success and Project Management Success Criteria and Factors: Literature Review and Survey. Wseas Transactions on Business and Economics 6: 456-468.

23. Omer, Haleema H (2017) Assessment of Projects Using Key Performance Indicators in Oil and Gas Companies, MSc Thesis, Supervised by Dr. Abdulbaset Frefer and Dr. Mahmoud Matoug, College of Engineering, University of Tripoli.

24. Iram N, Khan B, Sherani AW (2016) Critical Factors Influencing the Project Success: An Analysis of Projects in Manufacturing and Construction in Pakistan. Arabian Journal of Business and Management Review 6: 20-22.

25. Kenny J (2003) Effective Project Management for Strategic Innovation and Change in Organizational Context. Project Management Journal 34: 43-53.

26. Osorio PF, Quelhas OG, Zotes LP (2014) Critical Success Factors in Project Management: An Exploratory Study of an Energy Company in Brazil, Double Blind Peer Reviewed. International Research Journal 14: 39-50.

27. Srimathi S, Dinesh S, Sethuraman R (2017) A Review On Critical Success Factors In Construction Project. International Journal of Scientific Research in Science, Engineering and Technology 3: 478- 481.

28. Atkinson R (1999) Project Management: Cost, Time And Quality, Two Best Guesses and a Phenomenon, Its Time to Accept Other Success Criteria. International Journal of Project Management 17: 337-342.

29. Kylindri S, Blanas G, Henriksen L, Stoyan T (2012) Measuring Project Outcomes: A Review of Success Effectiveness Variables, MIBES, Larissa, Greece: 212-223.

30. Nicholas JM (1989) Successful Project Management: A Force-Field Analysis Journal of Systems Management 40: 164-70.

31. Project Management Institute (2013) A guide to the Project Management Body of Knowledge, fifth Edition USA

32. Westerveld E (2003) The Project Excellence Model: linking Success Criteria and Critical Success Factors. International Journal of Project Management 21: 411-418.

33. Freeman MA, Beale P (1992) Measuring Project Success. Project Management Journal 23: 8-17.

34. Khosravi S, Afshari H (2011) A Success Measurement Model for Construction Projects, International Conference on Financial Management and Economics, International Proceedings of Economics Development and Research (IPEDR) International Association of Computer Science and Information Technology (IACSIT) Press, Singapore 11: 186-190

35. Bryde DJ, Robinson L (2005) Client Versus Contractor Perspectives on Project Success Criteria. International Journal of Project Management 23: 622-629.

36. Bahia FD, de Farias Filho JR (2010) Analysis of Success Criteria in Engineering, Supplies and Construction (EPC) Projects. Journal of Business and Projects 1 : 49-67.

37. Al-Tmeemy SH, Abdul-Rahman H, Harun Z (2010) Future Criteria for Success of Building Projects in Malaysia. International Journal of Project Management 29: 337-348.

38. Gomesa J, Romao M (2016) Improving Project Success: A Case Study Using Benefits and Project Management. Procedia Computer Science 100: 489-497.

39. Mukhtar MM, Amirudin R (2016) The Success Criteria of Public Housing
Project in Nigeria. International Journal of Built Environment and Sustainability 3: $102-110$.

40. Toor SR, Ogunlana OS (2010) Beyond the 'Iron Triangle': Stakeholder Perception of Key Performance Indicators (KPIs) for Large-Scale Public Sector Development Projects. International Journal of Project Management 28 : 228-236.

41. Rockart JF (1979) Chief Executives Define Their Own Information Needs Harvard Business Review.

42. Baccarini D, Collins A (2003) Critical Success Factors for Projects, In Surfing the Waves: Management Challenges; Management Solutions, Proceedings of the 17th Australia \& New Zealand Academy of Management (ANZAM) Conference, Brown A editor. Fremantle, Western Australia.

43. Amade B, Ubani EC, Omajeh EO, Anita AU (2015) Critical Success Factors for Public Sector Construction Project Delivery: A Case of Owerri, Imo State. International Journal of Research in Management, Science and Technology 3: 11-21.

44. Alias, Z, Zawawi EM, Yusof K, Aris NM (2014) Determining Critical Success Factors of Project Management Practice: A Conceptual Framework. Procedia Social and Behavioral Sciences 153: 61-69.

45. Baccarini D (2009) Critical Success Factors in Construction Engineering Projects: A Case Study. AIPM09 Refereed Paper 1-14.

46. Pinto JK (1986) Project Implementation: A Determination of Its Critical Success Factors, Moderators, and Their Relative Importance across the Project Life Cycle. Doctorate dissertation, University of Pittsburgh.

47. Kerzner H (1987) In Search of Excellence in Project Management. Journal of Systems Management 38: 30-40.

48. Pinto JK, Prescott JE (1988) Variations in Critical Success Factors over the Stages in the Project Life Cycle. Journal of Management 14: 5-18

49. Belassi W, Tukel OI (1996) A New Framework for Determining Critical Success/ Failure Factors in Projects. International Journal of Project Management 14 141- 152.

50. Fortune J, White D (2006) Framing of Project Critical Success Factors by a System Model. International Journal of Project Management 24: 53-65.

51. Andersen ES, Birchall D, Jessen SA, Money AH (2006) Exploring Project Success, Baltic Journal of Management 1: 127-147

52. Khan RA, Spang K (2011) Critical Success Factors for International Projects, The 6th IEEE International Conference on Intelligent Data Acquisition and Advanced Computing Systems: Technology and Applications Prague, Czech Republic.

53. Fiberesima DD, Rani NS (2011) An Evaluation of Critical Success Factors in Oil and Gas Project Portfolio in Nigeria. African Journal of Business Management 5: 2378-2395.

54. Pakseresht A, Asgari G (2012) Determining the Critical Success Factors in Construction Projects: AHP Approach, Interdisciplinary Journal of Contemporary Research in Business 4: 383- 393.

55. Gudienè N, Banaitis A, Banaitienè N (2013) Evaluation of Critical Success Factors for Construction Projects - An Empirical Study in Lithuania. International Journal of Strategic Property Management 17: 21-31.

56. Almajed A, Mayhew P (2013) An Investigation of the Critical Success Factors of IT Projects in Saudi Arabian Public Organizations, IBIMA Business Review 1-10.

57. Ofori DF (2013) Project Management Practices and Critical Success Factors - A Developing Country Perspective. International Journal of Business and Management 8: 14-31.

58. Adnan H, Yusuwan NM, Yusof F, Bachik, F (2014) Critical Success Factors for Contractors. International Journal of Engineering and Technical Research 2: 107-113.

59. Banihashemi S, Hosseinib MR, Golizadehc H, Sankaranda S (2017) Critical Success Factors (CSFs) for Integration of Sustainability into Construction Project Management Practices in Developing Countries. International Journal of Project Management 1-17.

60. Wang, N, Yao S, Chiawu C, Jiang, D (2015) Critical Factors for Sustainable Project Management in Public Projects. International Association for Management of Technology 226- 237. 
Citation: Frefer AA, Mahmoud M, Haleema H, Almamlook R (2018) Overview Success Criteria and Critical Success Factors in Project Management. Ind Eng Manage 7: 244. doi:10.4172/2169-0316.1000244

61. Westerveld E (2003) The Project Excellence Model: Linking Success Criteria and Critical Success Factors. International Journal of Project Management 21: 411-418.

62. Silvius AG, Schipper R, Nedeskia S (2013) Sustainability in Project Management: Reality Bites. Procedia - Social and Behavioral Sciences 2: 1-14.

63. Silvius A G, Schipper R (2016) Exploring the Relationship between Sustainability and Project Success - Conceptual Model and Expected Relationships. International Journal of Information Systems and Project Management 4: 5-22.

64. (1987) World Commission on Environment and Development, Our Common Future, Oxford University Press Oxford.
65. Elkington J (1979) Cannibals with Forks: the Triple Bottom Line of 21st Century Business. Capstone Publishing, Oxford.

66. Tam G (2010) The Program Management Process with Sustainability Considerations. Journal of Project, Program and Portfolio Management 1: 17-27.

67. Ning, C, Zhang S, Li L (2009) Sustainable Project Management: A Balance Analysis Model of Effect. In: International Conference on Management and Service Science Wuhan, China 2321-2324.

68. Sadaba SM, Gonzalez-Jaen LF, Perez-Ezcurdia A (2015) Using Project Management as a Way to Sustainability, From a Comprehensive Review to a Framework Definition. Journal of Cleaner Production 99: 1-16. 